\title{
Reinforce Loyalty Model Based on Marketing Relationship, Satisfaction, Trust and Retention Program
}

\author{
Herni Justiana Astuti ${ }^{1}$ and Suryo Budi Santoso ${ }^{2}$ \\ \{herni99@gmail.com ${ }^{1}$,suryobs@gmail.com ${ }^{2}$ \} \\ ${ }^{1}$ Manajemen, Universitas Muhammadiyah Purwokerto \\ ${ }^{2}$ Akuntansi, Universitas Muhammadiyah Purwokerto
}

\begin{abstract}
The purpose of this research is to design a model of how subjects develop loyalty to beauty clinics through relationship marketing, patient satisfaction, trust and retention programs that will strengthen patient loyalty to beauty clinics. This study uses Structural Equation Modeling with Partial Least Square (PLS) approach. PLS-SEM analysis usually consists of two sub models namely measurement model or often called the outer model and structural model or often called the inner model. The questionnaire was distributed to respondents who had undergone the maintenance three times from November to December. Based on the purposive sampling method, there were 140 respondents. The instrument used for all valid and reliable variables. Based on the outer test the model is done twice because the indicators $\mathrm{KcP} 3$ and $\mathrm{KcP} 5$ are rejected because the Loading Factor value is $<0.07$. After the second round, all indicators have met the criteria for convergent validity. While the inner model test is obtained a loyalty model that is built by relationship marketing, customer trust, and retention programs in beauty clinic customers. Although customer satisfaction is not significant to influence the beauty loyalty of beauty clinics, the direction of the relationship is positive. In other words, customers are more satisfied but not always cause loyal customers.
\end{abstract}

Keyword: Loyalty, relationship marketing, customer trust, and retention programs

\section{Introduction}

Beauty care at this time has become a necessity for everyone, especially women with lifestyles who always pay attention to appearance and want beauty and perfection every time. These beauty care trends are making changes to existing market segments. In recent years many beauty clinics and body treatments have begun to emerge which have led to a growing market segment. The presence of various beauty clinics is a result of changes in people's lifestyles. This condition causes beauty clinics to enter an increasingly fierce competition phase.

Customer loyalty is absolutely necessary for a company to be able to survive and be able to compete with other companies. To build customer loyalty, it requires the efforts of the company to continue to provide the best quality in every product or service it has, so that a strong perception of quality is formed in the minds of consumers. Satisfied and loyal customers are opportunities to get new customers. Maintaining all existing customers will generally be more profitable than changing customers because the cost of attracting new customers can be five times the cost of maintaining an existing customer[1]. 
Service providers include customers in the product development process to build relationships. if a relationship impresses the customer, then the relationship is likely to be maintained in the long run [2]. According to Sanchez, one of the basic objectives of marketing is to determine customer values and to include them in marketing programs to increase customer loyalty[3]. A good relationship between customers and service providers can lead to satisfied customers[4]. Based on Sari's findings[5], relationship marketing does not affect customer satisfaction. This is different from the previous findings. Overall satisfaction is a significant and immediate precursor to loyalty[6]. Based on previous research, Salgaonkar believes that satisfaction with core services is important for overall customer satisfaction and, in turn, for customer loyalty. Also applies to beauty clinics[7]. In contrast to the findings of Astuti and Nagase[8] that although healthcare providers can increase patient satisfaction by demonstrating trustworthiness and commitment and by the use of good communication skills, these factors do not have a significant effect on loyalty despite their overall positive impact.

Each contact between the customer and the service system aspect ("service meeting") presents an opportunity to evaluate service providers and service quality, to form opinions, and to interact with other patients[7]. According to the Trust-Commitment theory[9] trust is a key variable for maintaining a long-term relationship, including a brand. Long-term relationship will increase the level of consumer trust in the expectations that will be received from the company. so that it will reduce consumer anxiety about the service it receives, so that it is a barrier in influencing consumers to make a selection (switching barrier).

A healthcare provider must also make efforts to drive customers back, and one way to approach this goal involves the development of a retention program. "Retention" refers to efforts to promote repeat visits. According to O'Malley[10] the basic approach of a loyalty program is to reward customers who buy multiple times.

A consumer who buys skin care and / or products and then comes back is not easy, because both have a high risk for consumers. If they choose the wrong choice, it will be fatal for consumers. Based on the findings of previous experts and several different studies, whether the enlargement relationship that is built can cause consumers to believe and be satisfied and then they become loyal? Discussions about beauty clinic patient loyalty, resulting from relationship marketing, trust, retention or from patient satisfaction, are important for health care organizations to sustain their efforts in the long run. The aim of this study is to design a model of how subjects develop loyalty to beauty clinics through relationship marketing, patient satisfaction, trust and retention programs that will strengthen the beauty clinic patients' loyalty.

\section{Literature Review}

\subsection{Patient Satisfaction}

For business customer satisfaction is seen as one of the dimensions of market performance. Increased customer satisfaction has the potential to lead to long-term and short-term sales growth, and market share as repeat purchases Tjiptono and Chandra[11], Kotler and Keller[1] definition of customer satisfaction is a feeling of pleasure or disappointment someone who appears after comparing the performance (results) of the product thought to the expected performance (or results). If performance is below expectations, the customer is not satisfied. If performance meets expectations, the customer is satisfied. If performance exceeds 
expectations, the customer is very satisfied or happy. Customer satisfaction and patient satisfaction cannot be the same, because health is usually a complex mixture of emotions, tangible and intangible, and health consumption cannot be seen. so patients are not ready to express their feelings about the health services they receive[12]. One patient said that sometimes they are satisfied using the assumption that patient satisfaction can be useful as an indicator of health[13].

\subsection{Relationship Marketing}

Nowadays, many service providers use relationship marketing strategies. Despite the old idea, relationship marketing is considered to be at the forefront of marketing practices for services. If the customer has no intention of establishing a relationship with the company, he can switch service providers at any time. On the other hand, if a customer is looking to establish a relationship, he will be willing to buy the product or service in question without having to be "forced" to do so[14]. Doyle[15] states that one of the pillars of relationship marketing is building satisfaction. This was also reinforced by the findings of Rizan et al[16], Astuti and Nagase [8], and Astuti and Nagase[17] states that relationship marketing influences significant positive on customer satisfaction.

Given the foregoing, I proposed the following hypothesis:

H1: Relationship marketing and patient satisfaction are significantly positively correlated

\subsection{Customer Trust}

According to the Trust-Commitment theory[9] trust is a key variable for maintaining a long-term relationship, including in a brand. Long-term relationship will increase the level of consumer trust in the expectations that will be received from the company so that it will reduce consumer anxiety about the service it receives, so that it is a barrier in influencing consumers to make a choice (switching barrier).

Viewed from the customer's point of view, important factors that are used to meet the needs of customers are trust, commitment, mutuality, and long-term relationships with customers. Priansa[18] states that trust is one party's belief in the reliability, durability, and integrity of the other party in the relationship and the belief that his actions are in the best interest and will produce positive results for the trusted party. That way if the success rate of relationship marketing is high, the customer trust is also high with the company. This is also supported by the research results of Rizan et al[16], stating that relationship marketing has a significant positive effect on customer trust.

Given the foregoing, I proposed the following hypothesis:

H2: Relationship marketing and customer trust are significantly positively correlated

\subsection{Customer Loyalty}

Loyalty is continuing to use a product or service and is based on an attitude towards the product or service. The difference between loyal and habitual usage is related to the dynamics that underlie the choice of a particular product or service. Astuti and Nagase explain patient loyalty in three groups, one of which is defined loyalty which reinforces loyalty[12]. Relationship marketing, patient satisfaction and retention programs are variables to build strengthened loyalty. Based on the results that loyalty will increase when there are interactive relationships that add value to patients with health care providers, appreciation, and happiness 
to care services that meet expectations and retention programs designed to encourage patients to return. Everything that is seen, heard, felt, and experienced by patients in the health care environment must instill trust[19]. Satisfied patients will have a high sense of trust and will not move to another place, even promoting the place to relatives or friends, other prospective patients to check the health of the primary health facilities. Satisfied patients can also trigger them to be loyal[20][8]. If the company is able to provide satisfaction to customers, then it will have an impact on the level of customer loyalty to the company, and vice versa. This is consistent with the results of research conducted by Rizan et al[16] that customer satisfaction has a significant positive effect on customer loyalty.

Given the foregoing, I proposed the following hypothesis:

H3: Customer Satisfaction and customer loyalty are significantly positively correlated

Increasing customer loyalty can also be done by creating customer trust. Mowen and Minor[21] states that trust is all knowledge owned by consumers and all conclusions consumers make about objects, attributes, and benefits. Society as a user of beauty products is now more selective in choosing providers. beauty clinic services, the higher the level of customer trust, the higher the customer perceived loyalty, which is in accordance with the results of research conducted by Astuti et al [22] that trust has a significant influence on customer loyalty. In this case the element of trust is a key factor for companies to win the competition. The beauty clinic business is a business based on the principle of trust supported by product superiority and value the customer becomes a very determining factor for success this business.

Given the foregoing, I proposed the following hypothesis:

H4: Customer trust and customer loyalty are significantly positively correlated

\subsection{Retention}

Health care providers must also make efforts to drive customers back, and one way to approach this goal involves developing a retention program. In the health service domain, 'retention' refers to efforts to promote repeat visits. The basic approach of a loyalty program is to reward customers who buy multiple times; thus, retention programs provide rewards / bonuses for loyal customers, always reminding them of the existence of products by continuing to provide information through strong advertising[10]. Even Bolton et al[23] argue that the loyalty program in this case is the retention of encouraging loyal customers. Likewise, the findings of Astuti and Nagase[17] that retention affects loyalty to the clinic.

Given the foregoing, I proposed the following hypothesis:

H5: Retention and customer loyalty are significantly positively correlated

\section{Method}

\subsection{Sample}

Respondents in the study were those who had bought beauty products and / or treatments at beauty care Purwokerto at least three times.

\subsection{Measurement}

Model evaluation using Smart PLS 3.0 can be done by assessing the results of the measurement model, namely through confirmatory factor analysis (CFA) by testing the 
validity (convergent validity and discriminant validity) and latent construct reliability. If it meets the criteria for the measurement model, then it is followed by an evaluation of the structural model and significant testing to test the effect between constructs or variables. PLS-SEM analysis usually consists of two sub models, namely the measurement model or often called the outer model and the structural model or often called the inner model.

In more detail, the analysis stages using PLS-SEM must go through at least five process stages where each stage will affect the next stage, namely (1) conceptualizing the model, (2) determining the algorithm analysis method, (3) determining the resampling method, (4) draw path diagrams and (5) model evaluation[24].

\subsection{Acceptance and Rejection of Hypotheses:}

The hypothesis is accepted if the $\mathrm{P}$ values are less than 0.05 .

\section{Result And Discussion}

The data in this study were obtained by distributing questionnaires to consumers of the Beauty Clinic in Purwokerto, namely Natasha, LBC, Navagreen and Reta who had performed the treatment at least 3 times. The number of questionnaires distributed was 150 questionnaires to consumers and 140 returned. There were 10 sets of questionnaires that were not feasible to be analyzed with a response rate of $93 \%$.

\subsection{Outer Model}

The instrument test results are valid and reliable. While based on the outer model test (see table 1), it is done twice because the $\mathrm{KcP} 3$ and $\mathrm{KcP} 5$ indicators are rejected because the Loading Factor value $<0.07$. After the second round all indicators meet the convergent validity criteria.

Table 1. Results of Converging Validity (Loading Factor) Rounds 1 and 2

\begin{tabular}{cccc}
\hline Variable & Indicators & Loading factor Run ${ }^{*}$ & Loading factor Run2 $^{*}$ \\
\hline Relationships Marketing & RM1 & 0,743 & 0,734 \\
& RM2 & 0,726 & 0,735 \\
& RM3 & 0,834 & 0,832 \\
Customer Trust & KcP1 & 0,706 & 0,800 \\
& KcP2 & 0,719 & 0,753 \\
& KcP3 & 0,629 & Rejected \\
& KcP4 & 0,782 & 0,841 \\
Customer Satisfaction & KcP5 & 0,624 & Rejected \\
& KP1 & 0,784 & 0,784 \\
& KP2 & 0,774 & 0,774 \\
Retention Programs & KP3 & 0,808 & 0,801 \\
& RP1 & 0,793 & 0,792 \\
& RP2 & 0,727 & 0,727 \\
Customer Loyalty & RP3 & 0,769 & 0,771 \\
& LP1 & 0,829 & 0,839 \\
& LP2 & 0,794 & 0,785 \\
\hline
\end{tabular}

*accepted if the Loading Factor is above 0.07 
Then the Average Variance Extracted (AVE) is calculated as illustrated in table 2

Tabel 2. Average Variance Extracted (AVE), Composite Reliability dan R square

\begin{tabular}{cccc}
\hline Variabels & $\begin{array}{c}\text { Average Variance } \\
\text { Extracted }(\text { AVE) }\end{array}$ & $\begin{array}{c}\text { Composite } \\
\text { Reliability }^{b}\end{array}$ & R square \\
\hline Relationships Marketing & 0,617 & 0,828 & \\
Customer Trust & 0,621 & 0,831 & 0,134 \\
Customer Satisfaction & 0,627 & 0,839 & 0,314 \\
Retention Programs & 0,591 & 0,811 & \\
Customer Loyalty & 0,583 & 0,807 & 0,459 \\
\hline a is accepted if Average Variance Extracted (AVE) $\geq 0,5[25]$ & \\
b is accepted ifComposite Reliability $\geq 0,6[26]$
\end{tabular}

The AVE value described in table 2 has a value $\geq 0.5$ as well as a Composite Reliability value $\geq 0.6$ so that all variables can be used to construct the model.

\subsection{Inner Model}

Figure 1 shows the customer loyalty model in terms of Relationship Marketing, Trust, Satisfaction and Retention Programs. Based on table 2 and figure 1 there is an R square value of 0.134 which illustrates that the customer trust variable can be explained by the relationship marketing variable at $13.4 \%$. Then the $\mathrm{R}$ square value of 0.314 illustrates that the customer satisfaction variable can be explained by the relationship marketing variable by $31.4 \%$. Furthermore, the R square value of 0.459 illustrates that customer loyalty variables can be explained by the relationship marketing, trust, customer satisfaction and retention program variables of $45.9 \%$.

Table 3 shows the relationships between variables, path coefficients and t statistics. The path coefficient of all relationships is positive, which means that if the relationship marketing variable, trust, customer satisfaction and the retention program go up will cause an increase in customer loyalty. When seen the results of $t$ statistics of all relationships are significant except the relationship between customer satisfaction and customer loyalty.

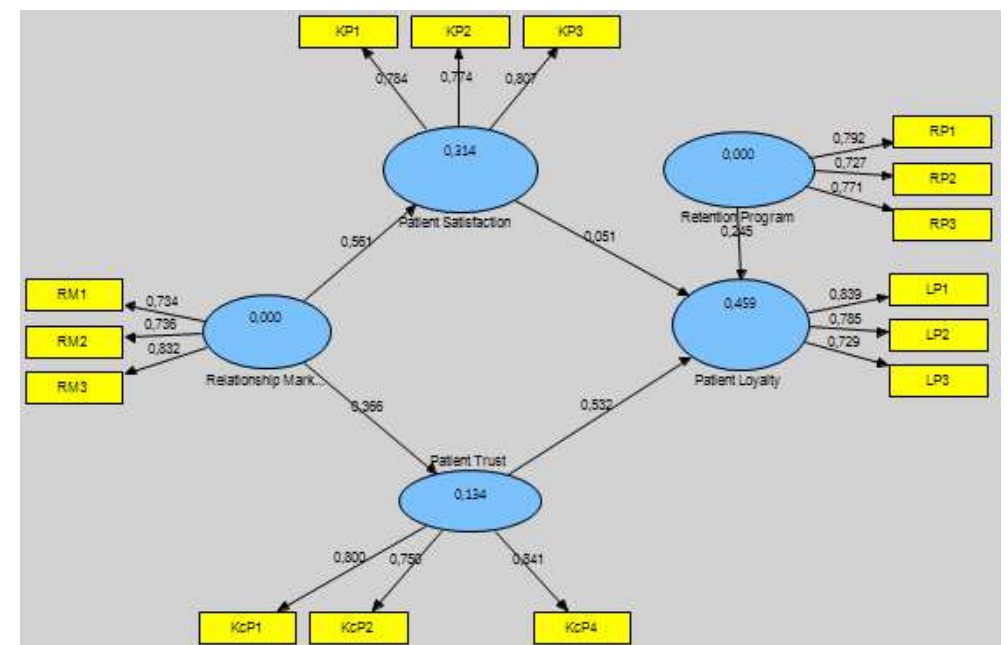

Fig.1. The structural equation model is from the loyalty model and is explained based on relationships marketing, customer satisfaction and trust and retention programs in beauty care clinics. 
Table 3. Relationships between variables, path coefficients and t statistics

\begin{tabular}{lll}
\hline Relationships between variables & path coefficients & t statistics \\
\hline Relationship Marketing $\rightarrow$ Customer Satisfaction & 0,561 & $8,018554^{*}$ \\
Relationship Marketing $\rightarrow$ Customer Trust & 0,366 & $4,435771^{*}$ \\
Customer Satisfaction $\rightarrow$ Customer Loyalty & 0,051 & 0,567310 \\
Customer Trust $\rightarrow$ Customer Loyalty & 0,532 & $5,630076^{*}$ \\
Retention Programs $\rightarrow$ Customer Loyalty & 0,245 & $3,588160^{*}$ \\
\hline
\end{tabular}

${ }^{*}$ _Significant at $5 \%$ error rate

\subsection{Discussion}

Value creation through the marketing relationship between the customer and the beauty clinic causes the customer to always look for a relationship, consumers will be willing to buy the product or service in question without having to be "forced" to do so. The beauty clinic always wants to establish an ongoing relationship with its customers. So as to create a long-term mutually beneficial relationship between the clinic and its customers.

The marketing relationship that is established fosters customer trust by entrusting therapeutic treatment for facial problems experienced at the beauty clinic. Customers feel that doctors, therapists and parties at the beauty clinic can communicate well with their customers. Communication is formed not only in one direction but from two directions, namely between the customer and the doctor, therapist and parties in the beauty clinic.

Long-term relationship will increase the level of customer confidence in the expectations that will be received from the company so that it will reduce consumer anxiety about the service it receives, so that it is a barrier in influencing consumers to make the transfer (switching barrier). All beauty businesses provide products for facial and skin care besides beauty therapy. Customers trust all beauty clinic products and can provide a safe feeling to use them in addition to being able to deal with facial care problems. The trust that the customer feels is also inseparable from the ability of the doctor or therapist to overcome the problem of facial care. So customers believe that all the promises delivered by beauty clinics foster a sense of security. Moreover, the beauty clinic is always open with all information about all facial care products. If the beauty clinic advises the customer to revisit the progress of the treatment then they will return to the treatment. With a variety of trust felt by these customers can cause them to become loyal. Even if there are other beauty clinics offering a variety of services and high value loyal customers remain firm in using these beauty clinics.

Unlike the case with the satisfaction felt by customers after they compare the performance with expectations. Feelings of pleasure that cause satisfaction still advise others to take care of the beauty clinic. Customers are satisfied but that is not always the reason they come back for treatment. Although the services provided by the beauty clinic are very appropriate between the costs incurred with the benefits obtained and assume the services provided are good.

Loyalty programs can be said to reward customers who buy multiple times; thus, the retention program gives rewards / bonuses to loyal customers, always reminding them of the existence of products by continuing to provide information on new clinical products and services. Loyalty programs that are carried out repeatedly can encourage customers to be loyal.

\section{Conclusions}

1. The loyalty model is built on relationship marketing, customer trust, and retention programs for beauty clinic customers. 
2. Although customer satisfaction is not significant to influence beauty clinic customer loyalty, the direction of the relationship is positive. In other words, more satisfied customers, but not always cause loyal customers.

Suggestions for future researchers are a model of the relationship between customer satisfaction and loyalty associated with switching clinics.

\section{Referensi}

[1] P. Kotler and K. L. Keller, Manajemen Pemasaran. Jakarta: Erlangga, 2009.

[2] C. Gronroos, Service Management and Marketing: Customer Management in Service Competition. Wiley, 2007.

[3] J. G. Sanchez, "Customer relationship marketing: building customer relationships for enduring profits in a wired economy," Res. Pap. Atthapholj. net, 2003.

[4] L. A. Anderson and M. A. Zimmerman, "Patient and physician perceptions of their relationship and patient satisfaction: a study of chronic disease management," Patient Educ. Couns., vol. 20, no. 1, pp. 27-36, 1993.

[5] Y. K. Sari, "Pengaruh Kualitas Pelayanan, Relationship Marketing dan Corporate Social Resposibility terhadap Loyalitas dan Kepuasan Nasabah Bank," J. Bisnis dan Manaj. (Journal Bus. Manag., vol. 17, no. 2, pp. 1-14, 2017.

[6] G. Bodet, "Customer satisfaction and loyalty in service: Two concepts, four constructs, several relationships," J. Retail. Consum. Serv., vol. 15, no. 3, pp. 156-162, 2008.

[7] P. B. Salgaonkar, Marketing of Healthcare Services: Patient Satisfaction and Loyalty. Abhijeet Publications, 2006.

[8] H. J. Astuti and K. Nagase, "Patient Loyalty To Healthcare Organizations: Relationship Marketing And Satisfaction," Int. J. Manag. Mark. Res., Mar. 2014.

[9] R. M. Morgan and S. D. Hunt, "The commitment-trust theory of relationship marketing," $J$. Mark., vol. 58, no. 3, pp. 20-38, 1994.

[10] L. O’Malley, "Can loyalty schemes really build loyalty?," Mark. Intell. Plan., 1998.

[11] F. Tjiptono and G. Chandra, "Service, quality \& satisfaction," Yogyakarta Andi Offset, 2005.

[12] H. J. Astuti, "Balancing Operational Services in Healthcare: An Indonesian Perspective," in Contemporary Issues and Research in Operations Management, GB, 2018.

[13] E. K. Mpinga and P. Chastonay, "Satisfaction of patients: a right to health indicator?," Health Policy (New. York)., vol. 100, no. 2-3, pp. 144-150, 2011.

[14] V. Kumar, T. R. Bohling, and R. N. Ladda, "Antecedents and consequences of relationship intention: Implications for transaction and relationship marketing," Ind. Mark. Manag., vol. 32, no. 8, pp. 667-676, 2003.

[15] P. Doyle and P. Stern, "Marketing Management and Strategy. Harlow." Pearson Education, 2002.

[16] M. Rizan, A. Warokka, and D. Listyawati, "Relationship marketing and customer loyalty: do customer satisfaction and customer trust really serve as intervening variables?," J. Mark. Res. Case Stud., vol. 2014, p. 1, 2014.

[17] H. J. Astuti and K. Nagase, "A framework for conceptualizing patient loyalty to healthcare organizations," Heal. Serv. Manag. Res., vol. 29, no. 3, pp. 70-78, 2016.

[18] D. J. Priansa, "Perilaku konsumen dalam persaingan bisnis kontemporer," Bandung Alf., 2017.

[19] K. Baird, Raising the bar on service excellence. eBookIt. com, 2013.

[20] H. J. Astuti and K. Nagase, "Patient loyalty to health care organizations: Strengthening and weakening (satisfaction and provider switching)," J. Med. Mark., 2014.

[21] J. C. Mowen and M. Minor, "Perilaku konsumen," Jakarta: Erlangga, vol. 90, 2002.

[22] H. J. Astuti, P. A. Aprilia, and A. J. Wijayanti, "Patient Loyalty to Helathcare Organization: Service Quality, Brand Image, Brand Trust, and Satisfaction (Study in Patient at Beauty Clinics)," in IBSS Proceedings, 2018, pp. 187-198. 
[23] R. N. Bolton, P. K. Kannan, and M. D. Bramlett, "Implications of loyalty program membership and service experiences for customer retention and value," J. Acad. Mark. Sci., vol. 28, no. 1, pp. 95-108, 2000.

[24] I. Ghozali and H. Latan, "Partial Least Squares, konsep, teknik dan aplikasi menggunakan program Smartpls 3.0 untuk penelitian empiris," Semarang: Badan Penerbit UNDIP, 2015.

[25] C. Fornell and D. F. Larcker, "Evaluating structural equation models with unobservable variables and measurement error," J. Mark. Res., vol. 18, no. 1, pp. 39-50, 1981.

[26] R. P. Bagozzi and Y. Yi, "On the evaluation of structural equation models," J. Acad. Mark. Sci., vol. 16 , no. 1 , pp. 74-94, 1988. 